\title{
RANCANG BANGUN SISTEM PAKAR UNTUK DETEKSI PENYAKIT PARU-PARU DENGAN METODE FORWARD CHAINING
}

\author{
Karyo Budi Utomo ${ }^{1}$, Tien Rahayu Tulili², Mariani Limbong ${ }^{3}$ \\ ${ }^{1,2}$ Program Studi Teknologi Rekayasa Komputer, ${ }^{3}$ Teknik Informatika Multimedia \\ Politeknik Negeri Samarinda \\ email: $\underline{\text { kbu@polnes.ac.id }}{ }^{1)}$, ${\underline{\text { tien.tulili@ } \text { polnes.ac.id }^{2}}, \text { Marianilimbong0@ gmail.com }}^{3)}$
}

\begin{abstract}
Abstrak - Memiliki tubuh sehat merupakan dambaan setiap manusia, namun cukup banyak penyakit yang terlambat di diagnosis sehingga mencapai tahap kritis yang sulit untuk disembuhkan, salah satu diantaranya adalah penyakit paruparu pada manusia. Untuk itu dalam upaya membantu mendiagnosa penyakit paru-paru sejak dini diperlukan sebuah sistem pakar yang mampu mendiagnosa penyakit paru-paru sebelum dilakukan diagnosa yang lebih lanjut di rumah sakit. Dalam mewujudkan terciptanya sistem pakar deteksi penyakit paru-paru digunakan metode forward chaining, yang mana strategi penarikan kesimpulan dimulai dari sejumlah fakta-fakta yang telah diketahui, untuk mendapatkan suatu fakta baru dengan memakai aturan-aturan yang memiliki premis yang cocok dengan fakta dan terus dilanjutkan sampai mendapatkan tujuan atau sampai tidak ada aturan yang punya premis yang cocok atau sampai mendapatkan fakta. Hasil dari penelitian ini berupa perancangan dan perangkat lunak sistem pakar untuk deteksi penyakit paru-paru.

Kata kunci - Penyakit paru-paru, Sistem Pakar, Metode Forward Chaining.
\end{abstract}

\section{Pendahuluan}

Kesehatan merupakan hal yang sangat penting dalam kehidupan. Ironisnya, banyak sekali penyakit-penyakit yang terlambat didiagnosis sehingga mencapai tahap kronis yang sulit untuk disembuhkan contohnya adalah penyakit paru-paru pada manusia. Paru-paru adalah organ yang berfungsi untuk menukar oksigen dengan karbondioksida didalam darah yang prosesnya ini disebut respirasi atau pernafasan [1].

Seiring dengan berkembangnya teknologi komputer, dimana layanan dan informasi disajikan secara cepat dan mudah, maka mendorong penulis untuk dapat menyajikan suatu alat bantu berupa perangkat lunak yang menggunakan prinsip-prinsip kerja seorang pakar (pengetahuan manusia) yang dikemas dalam sebuah perangkat lunak, sehingga diharapkan dapat memudahkan masyarakat mendeteksi penyakit paru-paru sejak dini sebelum dilakukan pemeriksaan lebih lanjut ke rumah sakit.

Sistem pakar atau expert system merupakan salah satu bidang yang menggunakan kecerdasaan buatan. Secara umum sistem pakar adalah sebuah sistem yang kinerjanya mengadopsi keahlian yang dimiliki seorang pakar dalam bidang tertentu ke dalam system atau program komputer yang disajikan dengan tampilan yang dapat digunakan oleh pengguna yang bukan seorang pakar sehingga dengan sistem tersebut pengguna dapat membuat sebuah keputusan atau menentukan kebijakan layaknya seorang pakar [2]. Dengan sistem pakar ini, orang awampun dapat menyelesaikan masalah yang cukup rumit yang sebenarnya hanya dapat diselesaikan dengan bantuan para ahli [3].

Sistem pakar deteksi paru-paru dikembangkan dengan menggunakan metode forward chaining. Metode forward chaining adalah strategi penarikan kesimpulan yang dimulai dari sejumlah fakta-fakta yang telah diketahui, untuk mendapatkan suatu fakta baru dengan memakai aturan-aturan yang memiliki premis yang cocok dengan fakta dan terus dilanjutkan sampai mendapatkan tujuan atau sampai tidak ada rule yang punya premis yang cocok atau sampai mendapatkan fakta [4].

Sistem pakar dengan metode forward chaining dapat membantu masyarakat untuk mengetahui penyakit paru-paru yang dialami oleh pasien tersebut tanpa harus pergi keseorang dokter terlebih dahulu.

\section{Metode}

Langkah-langkah dalam penyelesaian penelitian ini meliputi :

a. Pengumpulan data salah satu upaya yang dilakukan dalam pengumpulan data adalah dengan melakukan observasi. Dalam hal ini dilakukan dengan cara mempelajari permasalahan tentang penyakit paru-paru. Hal ini dilakukan untuk menentukan pengetahuan yang akan diperlukan oleh sistem. Observasi dilakukan pada di RSUD.I.A .jln.H.A.M.M. Rifaddin Samarinda Seberang.

b. Basis Pengetahuan

Basis pengetahuan merupakan inti dari suatu sistem pakar, yaitu berupa representasi pengetahuan dari pakar. Basis pengetahuan tersusun atas fakta dan kaidah. Fakta adalah informasi tentang objek, peristiwa, atau situasi [5].

c. Analisis Data

Berdasarkan data yang telah dikumpulkan serta infromasi lain berbasis pengetahuan, selanjutnya dilakukan analisis data, dalam analisis ini pendekatan dilakukan dengan menggunakan metode forward chaining.

d. Pengembangan perangkat lunak

Perangkat lunak dikembangkan berdasarkan hasil analisis, dan dibangun dengan berbasis 
JUST TI Volume 12 Nomor 1, Januari 2020: 1 - 7

ISSN: 2579-4510(online) ISSN: 2085-6458(print)

web sehingga diharapkan dapat memudahkan masyarakat dalam mengaksesnya.

e. Pengujian perangkat lunak

Pengujian dilakukan dengan menggunakan metode Blackbox testing. Blackbox Testing merupakan Teknik pengujian perangkat lunak yang berfokus pada spesifikasi fungsional dari perangkat lunak [6] [7]. Blackbox Testing bekerja dengan mengabaikan struktur kontrol sehingga perhatiannya difokuskan pada informasi domain [7].

Tahapan dalam penelitian ini dapat ditujunjukan seperti pada Gambar 1. Sebagai berikut :

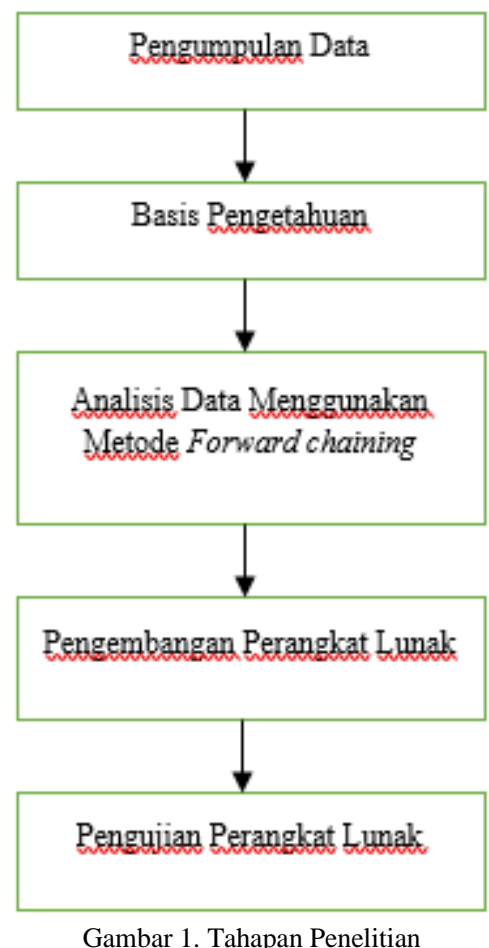

\section{HASIL DaN PEMBahasan}

Basis pengetahuan merupakan inti dalam program sistem pakar karena semua pengetahuan yang terkandung merupakan pengetahuan dari seorang pakar yang diperlukan untuk memahami, dan memecahkan masalah. Berdasarkan analisis sistem ini, akan diuraikan tentang analisis permasalahan yang ada dan analisis kebutuhan akan perangkat lunak yang nantinya akan dibuat yaitu membangun aplikasi sistem pakar untuk mendeteksi penyakit paru-paru berdasarkan gejalagejala yang dirasakan oleh pasien/pengguna . Sistem pakar untuk mendeteksi penyakit paru-paru menggunakan metode inferensi runut maju (Forward Chaining). Pemilihan metode ini didasari karena metode ini cocok diterapkan untuk melakukan diagnosa tentang mendeteksi penyakit paru-paru. Adapun Penyakit paru-paru yang di pilih hanya 5 (lima) penyakit, yaitu penyakit Abses Paru, Bronkitis, Kanker Paru, Pneumonia, dan tuberkulosis Paru.

Berikut ini adalah tabel kode dan gejala yang ada pada penyakit paru-paru dapat dilihat pada Tabel 1 .

Tabel 1 Gejala penyakit

\begin{tabular}{c|c|c}
\hline No & Kode & Gejala \\
\hline 1 & G1 & Demam \\
\hline 2 & G2 & Batuk \\
\hline 3 & G3 & Berat Badan Turun \\
\hline 4 & G4 & Malaise \\
\hline 5 & G5 & Hemoptysis \\
\hline 6 & G6 & Batuk $\geq 3$ minggu. Darah \\
\hline 7 & G7 & Sesak Nafas \\
\hline 8 & G8 & Sakit Dada \\
\hline 9 & G9 & melebihi 38 C \\
\hline 10 & G10 & Batuk Berdahak \\
\hline 11 & G11 & Suhu tubuh meningkat dapat \\
\hline 12 & G12 & Batuk berdahak $\geq 2$ minggu. \\
\hline 13 & G13
\end{tabular}

Jenis penyakit paru-paru terdapat kode sesuai dengan masing-masing penyakit. Data penyakit paru-paru yang di pilih hanya 5 (Lima) jenis penyakit paru-paru dapat dilihat pada Tabel 2, berikut ini,

Tabel 2 Jenis Penyakit

\begin{tabular}{l|l|l}
\hline No & Kode & \multicolumn{2}{|c}{ Penyakit } \\
\hline 1 & P1 & Abses Paru \\
\hline 2 & P2 & Bronkitis \\
\hline 3 & P3 & Kanker Paru \\
\hline 4 & P4 & Pneumonia \\
\hline 5 & P5 & Tuberkulosis Paru \\
\hline \multicolumn{2}{|c}{ Daftar hubungan gejala dan penyakit }
\end{tabular}
berikut ini Penyakit paru-paru beserta gejala dalam bentuk representasi pengetahuan dari pakar, dapat dilihat pada Tabel 3. Berikut ini,

Tabel 3 Daftar Hubungan gejala dan Penyakit 


\begin{tabular}{|c|c|c|c|c|c|c|c|}
\hline \multirow[b]{2}{*}{ No } & \multirow[b]{2}{*}{ Gejala } & \multirow[b]{2}{*}{$\begin{array}{l}\text { Kode } \\
\text { Gejala }\end{array}$} & \multicolumn{5}{|c|}{ Penyakit } \\
\hline & & & $\begin{array}{l}\text { Abses } \\
\text { Paru } \\
\text { (P1) } \\
\end{array}$ & $\begin{array}{l}\text { Bronkitis } \\
\text { (P2) }\end{array}$ & \begin{tabular}{|l|} 
Kanker \\
Paru \\
$(\mathrm{P} 3)$ \\
\end{tabular} & $\begin{array}{l}\text { Pneumonia } \\
\text { (P4) }\end{array}$ & $\begin{array}{l}\text { Tuberkulosis } \\
\text { Paru } \\
\text { (P5) }\end{array}$ \\
\hline 1 & Demam & G1 & $\mathrm{x}$ & $\mathrm{X}$ & $\mathrm{X}$ & $\mathrm{x}$ & $\mathrm{x}$ \\
\hline 2 & Batuk & G2 & $\mathrm{x}$ & $\mathrm{x}$ & $\mathrm{X}$ & & $\mathrm{x}$ \\
\hline 3 & $\begin{array}{l}\text { Berat Badan } \\
\text { Turun }\end{array}$ & G3 & $\mathrm{x}$ & & $\mathrm{x}$ & & $\mathrm{x}$ \\
\hline 4 & Nyeri Dada & G4 & $\mathrm{X}$ & & & $\mathrm{X}$ & $\mathrm{X}$ \\
\hline 5 & Malaise & G5 & $\mathrm{x}$ & & & & $\mathrm{x}$ \\
\hline 6 & Hemoptysis & G6 & $\mathrm{X}$ & & & & \\
\hline 7 & $\begin{array}{l}\text { Batuk } \\
\text { 3minggu. }\end{array}$ & G7 & & $\mathrm{X}$ & & & \\
\hline 8 & Batuk Darah & G8 & & & $\mathrm{X}$ & & $\mathrm{X}$ \\
\hline 9 & Sesak Nafas & G9 & & & $\mathrm{X}$ & $\mathrm{x}$ & $\mathrm{x}$ \\
\hline 10 & Sakit Dada & G10 & & $\mathrm{X}$ & $\mathrm{X}$ & & \\
\hline 11 & $\begin{array}{l}\text { suhu tubuh } \\
\text { meningkat } \\
\text { dapat } \\
\text { melebihi } \\
38^{\circ} \mathrm{C} \\
\end{array}$ & G11 & & & & $\mathrm{x}$ & \\
\hline 12 & $\begin{array}{l}\text { Batuk } \\
\text { berdahak }\end{array}$ & G12 & & & $\mathrm{x}$ & & \\
\hline 13 & $\begin{array}{l}\text { Batuk } \\
\text { berdahak } \geq 2 \\
\text { minggu. }\end{array}$ & G13 & & & & & $\mathrm{x}$ \\
\hline
\end{tabular}

\subsection{Implementasi metode Forward Chaining}

Forward Chaining berarti menggunakan himpunan aturan kondisi-aksi. Dalam metode ini, data digunakan untuk menentukan aturan mana yang akan dijalankan, kemudian aturan tersebut dijalankan. Mungkin proses menambahkan data ke memori kerja. Proses diulang sampai ditemukan suatu hasil. Metode inferensi runut maju cocok digunakan untuk menangani masalah pengendalian (controlling) dan peramalan (prognosis). Dalam tahapan ini dilakukan pencarian dan pengumpulan data serta pengetahuan yang diperoleh dari pakar. Sehingga analisa yang didapat berupa sistem pakar yang strukturnya dapat dipahami dengan jelas dan baik. Untuk mendapatkan hasil kepastian seorang pakar terhadap suatu data, dan data yang menentukan hasil penyakit paru-paru adalah jika pasien atau pengguna mengalami Semua gejalagejala yang sudah di tetapkan oleh pakar itu akan terpenuhi. Setelah semua dipastikan cocok maka akan merujuk pada sebuah penyakit yang sudah di tentukan oleh pakar dengan gejala-gejala yang di alami oleh pasien tersebut.

1. Abses paru adalah pengumpulan setempat cairan terinfeksi, berupa pus atau jaringan nekrotik dalam suatu kavitas yang terbentuk akit penghancur jaringan sekitarnya. Berikut ini adalah tabel aturan metode dapat dilihat pada Tabel 4.

Tabel 4 Aturan Penyakit Abses Paru (P1)

\begin{tabular}{l|l}
\hline No & \multicolumn{1}{c}{ Aturan } \\
\hline 1 & If G1 and G2 then G3 \\
\hline 2 & If G4 Then G5 \\
\hline 3 & If G5 Then G6 \\
\hline 4 & If G3 and G6 Then P1 \\
\hline
\end{tabular}

Pada Tabel 4. Terdapat 4 (Empat) aturan yang tersimpan dalam basis Pengetahuan dengan fakta awal yang diberikan G1,G2 dan G3, pada no 1. Kemudian berlanjut ke no 2 sampai menentukan kesimpulan akhir. Sedangkan Alur Inferensinya dapat dilihat pada Gambar 2.

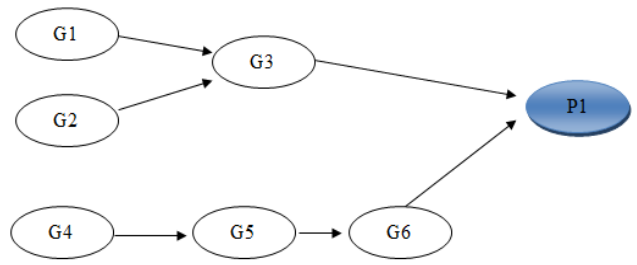

Gambar 2. Alur Infersi Penyakit Abses Paru

Dari Gambar 2. Dapat di jelaskan bahwa G1,G2,G3,G4,G5 dan G6 menyatakan gejala penyakit sedangkan P1 menyatakan penyakit. Alur inferensi dengan metode Forward Chaining pada Gambar 2. Tersebut dimulai dari kiri terlebih dahulu. Gejala penyakit dalam hal ini merupakan fakta. Dimulai dari gejala yang umum terjadi yang kemudian diuji satu persatu sampai mencapai gejala spesifik. Sehingga memperoleh kesimpulan akhir berupa jenis penyakit P1 ( Abses paru) .

2. Bronkitis adalah suatu peradangan pada bronkus yang disebabkan oleh infeksi saluran nafas yang di tandai dengan batuk berdahak atau tidak berdahak. Berikut ini adalah able aturan metode forward chaining dapat dilihat pada tabel 5 .

Tabel 5 Aturan Penyakit Bronkitis (P2)

\begin{tabular}{c|l}
\hline No & \multicolumn{1}{c}{ Aturan } \\
\hline 1 & If G1 and G2 Then G7 \\
\hline 2 & If G7 and G10 Then P2 \\
\hline
\end{tabular}

Pada Tabel 5. Terdapat 2 (Dua) aturan yang tersimpan dalam basis pengetahuan. Dengan fakta awal yang diberikan G1,G2 dan G7, pada no 1 . Kemudian berlanjut ke no 2 sampai menentukan kesimpulan akhir. Sedangkan Alur Inferensinya. Dapat dilihat pada gambar 3 . 


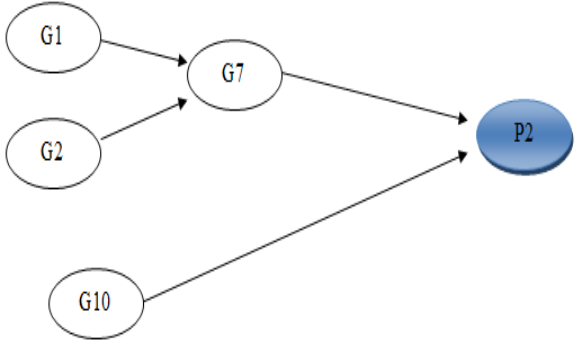

Gambar 3 Alur Penyakit Bronkitis

Dari Gambar 3 dapat di jelaskan bahwa G1,G2,G7 dan G110 menyatakan gejala penyakit sedangkan P2 menyatakan penyakit. Alur inferensi dengan metode Forward Chaining pada Gambar 3. Tersebut dimulai dari kiri terlebih dahulu. Gejala penyakit dalam hal ini merupakan fakta. Dimulai dari gejala yang umum terjadi yang kemudian di uji satu persatu sampai mencapai gejala spesifik. Sehingga memperoleh kesimpulan akhir berupa jenis penyakit P2 (Bronkitis).

3. Kanker paru adalah tumor ganas yang berasal dari epitei bronkus atau karsinoma bronkus. Tabel 6. Berikut ini adalah aturan metode Forward Chaining

Tabel 6 Aturan Kanker Paru (P3)

\begin{tabular}{c|l}
\hline \multicolumn{1}{c}{ No } & \multicolumn{1}{c}{ Aturan } \\
\hline 1 & If G1 and G2 Then G3 \\
\hline 2 & If G8 Then G9 \\
\hline 3 & If G9 Then G10 \\
\hline 4 & If G10 Then 12 \\
\hline 5 & If G3 And G12 Then P3 \\
\hline
\end{tabular}

Pada Tabel 6. Terdapat 5 (lima) aturan yang tersimpan dalam basis pengetahuan. Dengan fakta awal yang diberikan G1, G2 dan G3, pada no 1 . Kemudian berlanjut ke no 2 sampai menentukan kesimpulan akhir. Sedangkan alur Inferensinya dapat dilihat pada Gambar 4, berikut ini

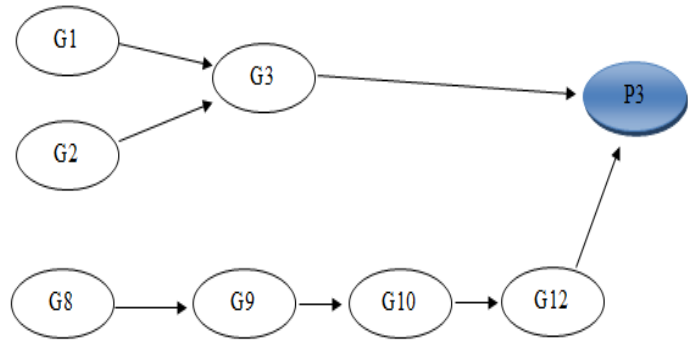

Gambar 4 Alur Penyakit Kanker Paru

Dari Gambar 4. Dapat dijelaskan bahwa G1,G2,G3,G8,G9,G10 dan G12 menyatakan gejala penyakit sedangkan P3 menyatakan penyakit. Alur inferensi dengan metode Forward Chaining pada gambar 4 tersebut dimulai dari kiri terlebih dahulu. Gejala penyakit dalam hal ini merupakan fakta. Dimulai dari gejala yang umum terjadi yang kemudian di uji satu persatu sampai mencapai gejala spesifik. Sehingga memperoleh kesimpulan akhir berupa jenis penyakit P3 ( Kanker Paru) .

4. Pneumonia adalah peradangan parekim paru yang disebabkan oleh bakteri, virus maupun parasit. Berikut ini adalah tabel aturan metode forward chaining dapat di lihat pada Tabel 7 .

Tabel 7 Aturan Pneumonia (P4)

\begin{tabular}{c|c}
\hline No & \multicolumn{1}{c}{ Aturan } \\
\hline 1 & If G1 and G4 Then G9 \\
\hline 2 & If G9 And G11 Then P4 \\
\hline
\end{tabular}

Pada Tabel 7. Terdapat 2 (Dua) aturan yang tersimpan dalam basis pengetahuan. Dengan fakta awal yang diberikan G1,G2 dan G9, pada no 1 . Kemudian berlanjut ke no 2 sampai menentukan kesimpulan akhir. Sedangkan Alur Inferensinya dapat dilihat pada Gambar 5

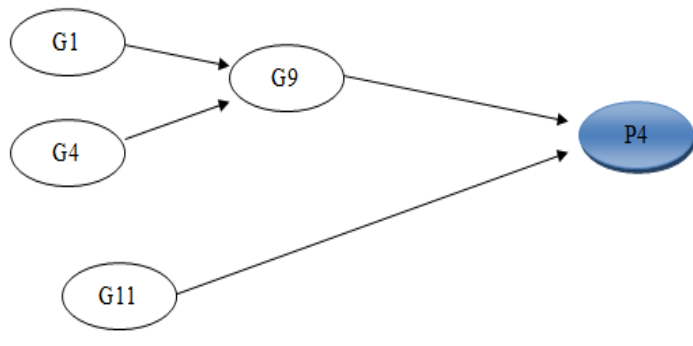

Gambar 5 Alur Penyakit Pneumonia

Dari Gambar 5 dapat di jelaskan bahwa G1, G2, G9 dan G11 menyatakan gejala penyakit sedangkan $\mathrm{P} 4$ menyatakan penyakit. Alur inferensi dengan metode Forward 
Chaining pada gambar tersebut dimulai dari kiri terlebih dahulu. Gejala penyakit dalam hal ini merupakan fakta. Dimulai dari gejala yang umum terjadi yang kemudian diuji satu persatu sampai mencapai gejala spesifik. Sehingga memperoleh kesimpulan akhir berupa jenis penyakit P4 (Pneumonia).

5. Tuberkolosis paru adalah penyakit menahun bahkan dapat seumur hidup setelah seseorang terinfeksi kuman tuberkolosis. Berikut ini adalah tabel aturan metode Forward Chaining dapat di lihat pada Tabel 8

Tabel 8 Aturan Tuberkulosis Paru (P5)

\begin{tabular}{l|l}
\hline No & \multicolumn{1}{c}{ Aturan } \\
\hline 1 & If G1 and G2 Then G3 \\
\hline 2 & If G4 Then G5 \\
\hline 3 & If G5 Then G8 \\
\hline 4 & If G8 Then G9 \\
\hline 5 & If G9 Then G13 \\
\hline 6 & If G3 and G13 Then P5 \\
\hline
\end{tabular}

Pada Tabel 8 Terdapat 6 (enam) aturan yang tersimpan dalam basis pengetahuan. Dengan fakta awal yang diberikan G1,G2 dan G3, pada no 1 . Kemudian berlanjut ke no 2 sampai menentukan kesimpulan akhir. Sedangkan Alur Inferensinya dapat dilihat pada Gambar 6.

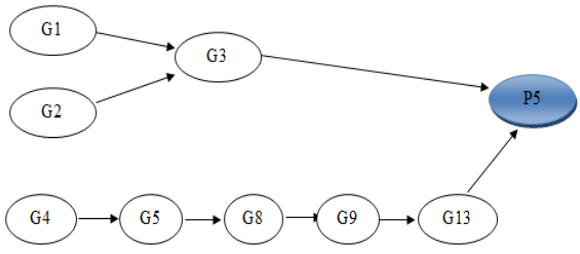

Gambar 6 Alur Penyakit Tuberkulosis Paru

Dari Gambar 6 dapat di jelaskan bahwa G1,G2,G3,G4,G5,G8 G9 dan G13 menyatakan gejala penyakit sedangkan P5 menyatakan penyakit. Alur inferensi dengan metode Forward Chaining pada gambar tersebut dimulai dari kiri terlebih dahulu. Gejala penyakit dalam hal ini merupakan fakta. Dimulai dari gejala yang umum terjadi yang kemudian di uji satu persatu sampai mencapai gejala spesifik. Sehingga memperoleh kesimpulan akhir berupa jenis penyakit P5 (Tuberkulosis paru).

\subsection{Implementasi aplikasi Sistem pakar}

\subsubsection{User Pasien}

Setiap pasien yang ingin melakukan diagnosa penyakit paru-paru wajib melakukan daftar jika belum mempunyai akun, akan tetapi jika pasien sudah mempunyai akun maka pasien tidak perlu melakukan daftar lagi tetapi hanya melakukan log in saja. Tampilan login pasien dapat di lihat pada Gambar 7.

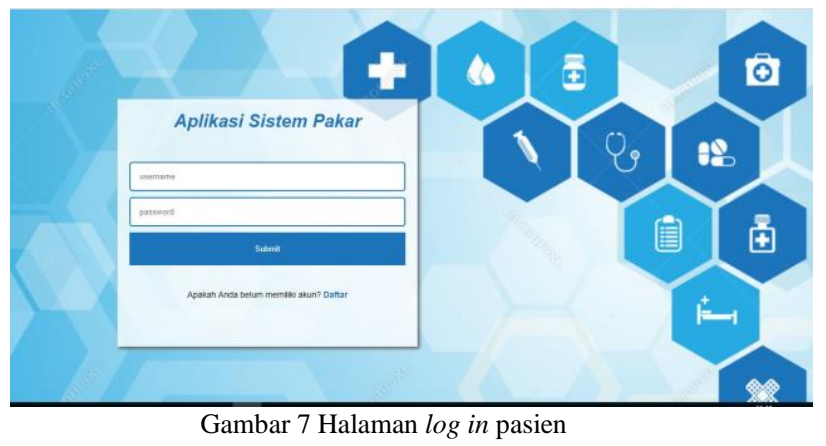

a. Halaman Daftar Pasien

Jika ingin melakukan diagnosa penyakit paruparu dan belum mempunyai akun wajib untuk melakukan pendaftaran agar mendapatkan username dan password agar dapat masuk ke dalam diagnosa penyakit paru-paru maka lakukan pendaftaran. Tampilan daftar pasien dapat dilihat pada Gambar 8,

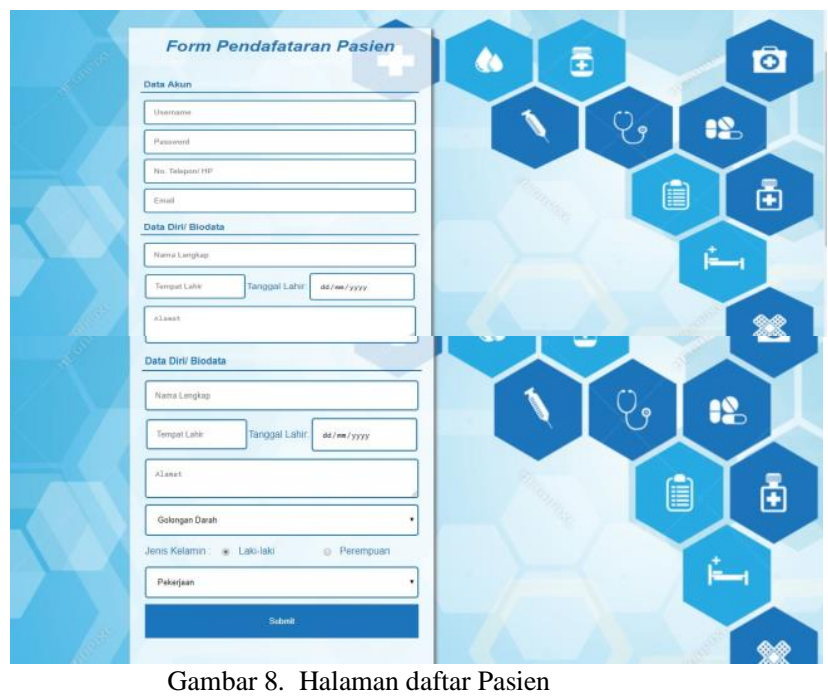

b. Halaman Pertanyaan Diagnosa

Setelah pasien melakukan diagnosa maka pasien wajib menjawab setiap pertanyaan yang muncul sesuai dengan gejala yang dialami, agar mendapatkan hasil penyakit yang dialami oleh pasien. Tampilan Pertanyaan diagnosa penyakit paru-paru dapat di lihat pada Gambar 9 
JUST TI Volume 12 Nomor 1, Januari 2020: 1 - 7

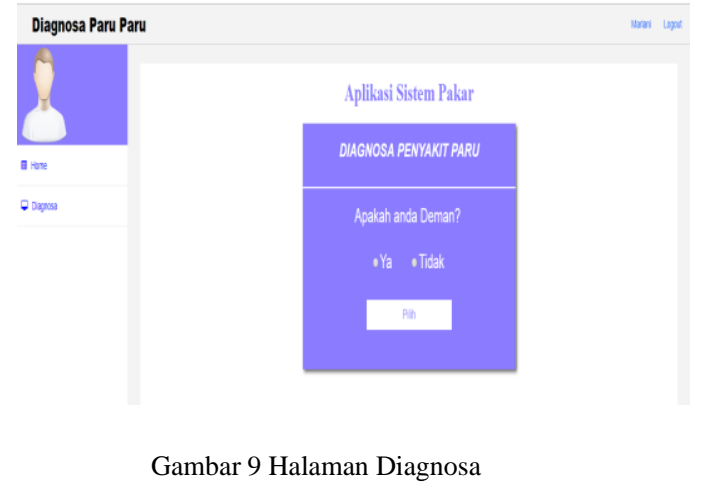

\subsubsection{User Admin}

Admin wajib melakukan $\log$ in, tetapi admin tidak dapat melakukan daftar selayaknya pasien, jika ingin melakukan pendaftaran, admin harus mengisi data melalui user utama. Setelah melakukan login maka halaman akan menuju kehalaman administrative untuk melakukan pemeliharaan data yang meliputi data penyakit, data gejala, serta menyusun relasi penyakit berdasarkan gejala. Selain itu dalam user admin juga memungkinkan melakukan diagnose penyakit paru-paru serta mengetahui biodata pasien yang telah melakukan registerasi.

a. Halaman Penyakit.

Menu penyakit yang ada di dalam halaman tersebut adalah untuk melihat semua jenis penyakit paru-paru yang ada di dalam tampilan penyakit tersebut, Selain itu admin juga bisa melakukan penambahan data, edit data dan hapus data. Tampilan penyakit dapat di lihat pada Gambar 10.

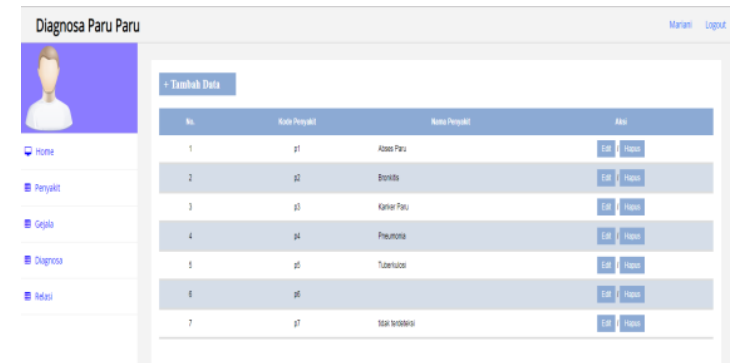

Gambar 10 Halaman data penyakit

b. Tampilan Gejala

Gejala yang ada di dalam tampilan tersebut adalah untuk melihat kode Gejala dan nama gejala tersebut. Selain itu admin juga bisa melakukan penambahan data, edit data dan hapus data. Tampilan gejala dapat di lihat pada Gambar 11.

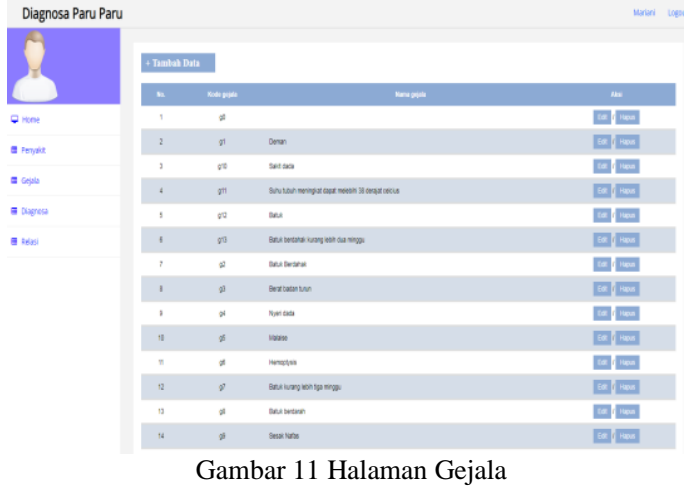

c. Tampilan Relasi

Relasi yang ada didalam tampilan tersebut adalah untuk melihat hasil sistem pakar penyakit paru-paru dengan metode Forward Chaining, Selain itu admin juga bisa melakukan penambahan data, edit data dan hapus data. Tampilan relasi dapat di lihat pada Gambar 12

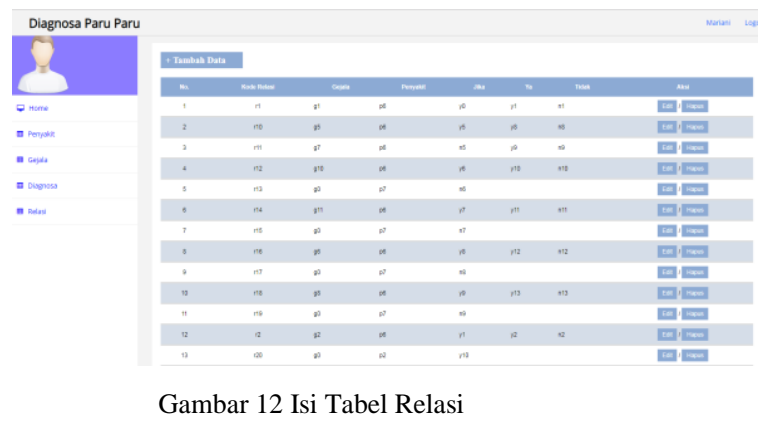

\subsection{Pengujian Aplikasi Sistem Pakar}

Dengan mempertimbangkan waktu yang cukup pendek serta biaya yang murah, maka Pengujian dilakukan dengan menggunakan metode Blackbox testing. Pengujian dilakukan dengan menjalankan tiap-tiap fungsionalitas sistem aplikasi dan untuk mendapatkan hasil yang maksimal atas perangkat lunak sistem pakar deteksi paru-paru, maka pengujian dilakukan oleh beberapa jenis profesi dan pihak yang berpotensi menggunakan perangkat lunak tersebut. Pihak-pihak yang terlibat dalam pengujian meliputi : 1) 3 orang dari masyarakat umum; 2) 2 orang dari staf rumah sakit, serta 3) 1 orang dokter selaku pakar dan merupakan sumber dari basis pengetahuan.

Hasil pengujian menunjukan bahwa setiap fungsionalitas perangkat lunak deteksi paru-paru berjalan sesuai dengan yang direncanakan, meski demikian terdapat beberapa usulan tambahan dari pakar demi kesempurnaan sistem. Diantaranya cakupan penyakit paru-paru sebaiknya tidak hanya terbatas pada 5 jenis penyakit paru-paru, tetapi lebih luas, baik yang berkaitan dengan penyakit paru-paru maupun penyakit lainya yang memiliki 
sedikit kesamaan dengan penyakit paru-paru dari sisi gejala.

\section{KESIMPULAN}

Berdasarkan analisa dan pengujian sistem yang telah dilakukan, maka sistem pakar deteksi penyakit paru-paru dengan metode Forward Chaining ini dapat ditarik kesimpulan sebagai berikut :

1. Hasil pengujian dengan menggunakan metode blackbox testing, dengan menguji fungsionalitas sistem pakar, menunjukan bahwa semua fungsi telah berjalan sesuai dengan yang direncanakan.

2. Perangkat lunak Sistem pakar deteksi penyakit paru-paru ini diharapkan dapat membantu masyarakat untuk mendiagnosa penyakit paruparu secara mandiri, cepat dan mudah sebelum dilakukan diagnose lebih lanjut ke rumah sakit.

3. Mengingat dalam penelitian ini hanya meliputi 5 (lima) jenis penyakit paru-paru, sehingga ada kemungkinan hasil diagnose kurang komprehensif karena diagnose menunjukan gejala jenis penyakit paru-paru lain yang tidak tercover dalam penelitian ini. Untuk itu diharapkan pada penelitian mendatang jenis penyakit paru-paru dapat lebih diperbanyak lagi, sehingga hasil diagnosa lebih komprehensif.

\section{REFERENSI}

[1] Lokendra.A.W, Ariadi.R.T.H.R, dan Dimas.W.W. "Sistem Pakar Diagnosa Awal Penyakit Pulmonologi Menggunakan Metode Naïve Bayes Dan Certainty Factor" Seminar Informatika Aplikatif, 31 Agustus 2018

[2] Anik Andriani. 2017. Pemrograman Sistem Pakar: Konsep Dasar dan Aplikasinya Menggunakan Visual Basic 6. Mediakom. Jogjakarta

[3] A. D. Lestyaningrum, dan Anardani, "Rancang Bangun Sistem Pakar Diagnosa Penyakit Tuberkulosis (TBC) dengan Metode Forward Chaining" Journal of Computer and Information Technology, Vol.1, No. 1, Agustus 2017.

[4] Puput.S.D., Ryana.D.L., dan Ryani.T.L. "Sistem pakar diagnosis penyakit ikan koi dengan metode Bayes" Komputa : Jurnal Ilmiah Komputer dan Informatika, Vol.4, No.1, Maret 2015.

[5] Arhami Muhammad. 2005. Konsep Dasar Sistem Pakar. Penerbit Andi. Yogyakarta.

[6] S. Roohullah Jan, S. Tauhid Ullah Shah, Z. Ullah Johar, Y. Shah, and F. Khan., 2016. An Innovative Approach to Investigate Various Software Testing Techniques and Strategies. Int. J. Sci. Res. Sci. Eng. Technol., vol. 2, no. 2, pp. 682-689.

[7] J. Watkins., 2001. Testing IT An Off The Shelf Software Testing Process. 